\title{
Factor Affecting the Capital Adequacy Ratio of Banks Listed in Indonesia Stock Exchange
}

\author{
Abdurrahman Setiawan ${ }^{1}$ and Susy Muchtar $^{2}$ \\ ${ }^{1,2}$ Faculty of Economic and Business, Trisakti University \\ Email Address: \\ abdul.setiawan1099@gmail.com; susy.muchtar@gmail.com
}

\begin{abstract}
The purpose of this study is to conclude the factors that affect bank capital adequacy ratios. The sample used is 42 banks listed on the Indonesia Stock Exchange in 2015-2019. The analysis method used was panel data regression and using purposive sampling for the sampling technique. The independent variables in this study are loan loss reserves, return on equity, bank size liquidity ratio and loan ratio, and capital adequacy ratio is the dependent variable. The results show that bank size and the return on equity have a positive effect on capital adequacy ratio, while loan ratio has a negative effect on capital adequacy ratio. The liquidity ratio and loan loss reserve have no effect on the capital adequacy ratio. It is expected that the results of this study will provide a reference for companies to understand the factors that affect capital adequacy. Managerial implications: Banking companies are expected to increase the total number of assets held, increase return on equity and reduce bank loan ratios to avoid the risk of bad credit.
\end{abstract}

Keywords: bank size, loan loss reserves, capital adequacy ratio, return on equity, liquidity ratio, loan ratio.

Abtrak: Penelitian ini bertujuan untuk mengetahui faktor-faktor yang mempengaruhi rasio kecukupan modal pada perbankan. Sampel yang digunakan sebanyak 42 bank yang terdaftar di Bursa Efek Indonesia periode tahun 2015-2019. Teknik pengambilan sampel yang digunakan yaitu purposive sampling dan metode analisa yang digunakan yaitu regresi dat panel. Variabel independen dalam penelitian ini adalah ukuran bank, cadangan kerugian pinjaman, pengembalian ekuitas, rasio likuiditas dan rasio pinjaman dan variabel dependen adalah rasio kecukupan modal. Hasil penelitian menunjukkan bahwa ukuran bank dan pengembalian ekuitas memiliki pengaruh positif dan rasio pinjaman memiliki pengaruh negatif terhadap rasio kecukupan modal. Cadangan kerugian pinjaman dan rasio likuiditas tidak memiliki pengaruh terhadap rasio kecukupan modal. Hasil penelitian ini diharapkan dapat dijadikan acuan bagi perusahaan dalam melihat faktor-faktor yang mempengaruhi rasio kecukupan modal. Implikasi manajerial: Perusahaan perbankan diharapkan meningkatkan jumlah total aset yang dimiliki, meningkatkan pengembalian ekuitas serta menurunkan rasio pinjaman bank agar terhindar dari risiko kredit macet.

Kata Kunci: cadangan kerugian pinjaman, pengembalian ekuitas, rasio kecukupan modal, rasio likuiditas, rasio pinjaman dan ukuran bank. 


\section{INTRODUCTION}

There was a Global Financial Crisis which affected the world economy in 20072008. Bank failures will affect the expansion of the market and financial system, thereby destroying the real economy (Turk-Ariss and Berger, 2015). Bank failures also caused a financial crisis, which adversely affected depositors. In order to protect depositors, market discipline and regulations on bank capital must be implemented as an important tool to protect depositors (Jumreornvong et al., 2018). Basel I provided formal capital requirements as banking rules in 1998. Basel II was resolved to alleviate the shortcomings of Basel I and for more effectively change risk-based capital regulations (Arshad et al., 2016).

The Basel III and Basel II are of great significance in maintaining adequate capital to ensure the smooth operation and bank solvency of the financial sector. This highlights the health and solvency of banks and calls for increasing bank capital. Quality and level (Afzal, 2015). If the bank's reserves are insufficient and the leverage ratio is high, it will lead to credit risk and liquidity. The capital adequacy ratio concludes the capital adequacy level. Maintaining high capital can reduce the economic costs of the banking crisis (Rochon and Fullenkamp, 2017). The increased capital ratio can protect the bank from future losses.

According to data as of the Financial Services Authority, since March 2020, Bank Indonesia's capital adequacy ratio has increased. According to the records of the Financial Services Authority, as of June 2020, the level of capital adequacy ratio is $22.59 \%$. This position continued to increase from the March 2020 period at the level of $21.67 \%$, the financial services authority also set a stimulus to keep the ratio at a safe level. Large banks such as PT Bank Panin Tbk, have a capital adequacy ratio of $25.94 \%$. This position continued to increase from a year earlier which amounted to $23.35 \%$. According to the President Director of PT Bank Panin (Herwidyatmo, 2020) stated that the capital owned by Bank Panin was already above Rp. 30 Trillion in June 2020, which means that Panin Bank has entered the BUKU IV bank group.

Profitability is a significant factor because retained earnings and capital have a positive effect on capital support. (Wedow and Stolz, 2011) realized a significant positive effect between profitability and solvency ratio. The loan ratio is a bank asset that is funded by lends or another financial liabilities that last for a long time or exceed one year. Research by (Thoa et al., 2020) shows that the loan ratio has a negative influence on the solvency ratio, but it is insignificant. (Asghari et al., 2014) estimated a study of a Iran's private banks sample and found that the loan to asset ratio has a significant and positive impact on the capital adequacy ratio.

The Loan Loss Reserve (LLR) is a cash preserve reserved by banks to predict possible losses caused by loans. Banks usually have sufficient reserves to protect expected losses on the loan portfolio. The results of Usman's Masood study. The results of (Ansari and Sanaullah, 2016) show that loan loss reserves have a significant and positive influence on capital adequacy ratio. The results of (Thoa et al., 2020) are inversely proportional to the previous studies results, namely, loan loss reserves have a insignificant and negative effect in the capital adequacy ratio. 
Liquidity is the banks ability to fulfill their financial obligations when they are due. In the banking world, liquidity is very worthy, because banks with good liquidity can make it easier for banks to maintain the trust of customers. The results of previous research conducted by (Ahmet, 2011) show that liquidity had no effect on the capital adequacy ratio of Turkish banks. The research showed by (Thoa et al., 2020) shows that liquidity has a significant and negative impact on capital adequacy ratio, which means that when bank have high liquid assets, if the bank does not have strategic management and business policies, the risk will be increase appropriate.

The total assets are used as a substitute for bank size. In fact, the relationship between bank size and the capital adequacy ratio can be positive or negative. A previous study accompanied by (Bateni et al., 2014) discovered that there is a negative correspondence between the capital adequacy ratio and bank size of Iranian private bank. The lower the capital adequacy ratio owned by the bank, the bigger the bank is. The results of other studies conducted by (Hyseni and Shingjergji, 2015) related to bank size are positively correlated with capital adequacy ratio. The bigger the bank, the greater the capital adequacy obtained by the bank or the smaller the bank, the smaller is the capital adequacy of a bank.

Based on the background description above and previous research conducted by (Thoa et al., 2020) in Vietnam in 2020, it shows the influence of bank size and liquidity ratio on the capital adequacy ratio, so researchers are interested in re-examining in Indonesia. Therefore, this study is entitled "Factors Affecting the Capital Adequacy Ratio of Banks Listed Indonesia Stock Exchange".

\section{THEORETICAL REVIEW}

Capital Adequacy Ratio. One of the truly significant topics in the industry of banking is to assess the banks stability and efficiency. The Basel Capital Accord is a standard of international use to determine the minimum Capital Adequacy Ratio (CAR) that banks must encounter to confirm the efficiency and stability of the financial system. In the event of a crisis of financial, the accord strengthened the bank's strength through regulatory agencies. In order to maintain and establish this relationship, banks must raise funds to increase their balance expanses, or, if they cannot raise more funds, they can reduce the amount of risky assets on their books.

Using the minimum capital adequacy ratio improves the stability efficiency of the financial system by decreasing the possibility of bankruptcy. After the financial crisis, regulators tried to strengthen banking. To achieve this goal, governments in developed countries are strengthening their weigh sheets by raising capital. If they cannot raise more capital, they must reduce the amount of risk assets on their books (Gabriel et al., 2013)

The application of Basel III in Indonesia is governed by Regulation No. 15/12/PBI/2013 concerning minimum capital obligations for banks. Therefore, bank regulations will be required to have an appropriate minimum capital based on their respective risks. 
Table 1. Minimum Capital Provision in Accordance with Bank Risk Profile Bank Risk

\begin{tabular}{c|c}
\hline Profile & Minimum Capital from Risk Weighted Assets (RWA) \\
\hline I & $8 \%$ \\
\hline II & $9 \% \leq 10 \%$ \\
\hline III & $10 \% \leq 11 \%$ \\
\hline IV \& V & $11 \% \leq 14 \%$ \\
\hline
\end{tabular}

The capital adequacy ratio is established in the form of adding risk weighted assets to the tier I of tier II, where the tier I (core capital) involves paid-in capital, general reserves, additional paid-in capital, destination reserves, and distribution of profits, last year's LAA and current year's profits. At the same time, the tier II (supplementary capital) contains asset revaluation reserves, classified asset reserves, quasi capital and subordinated loans. The purpose of capital adequacy is to promote financial stability so that they can play their respective roles. At present, in China, whether in the financial sector, the most important discussion is that the connection between banking behaviours and another financial sectors is deepening, and it is possible that non-banking activities may undermine financial stability. Because it intensifies the risk level of banking activities (Bateni et al., 2014).

Bank Size. Total assets natural logarithms are used to represent the bank size. The size of a bank is a valuable aspect because it is interconnected with financial markets to facilitate access to capital. The bigger the bank, the more assets the bank has. (Ahmet, 2011) believes that bank size is significant as bank size is thoroughly correlated to access of capital reflects the bank's interest and bank ownership in escaping managing risk or bankruptcy.

According to the results of (Ahmet, 2011), it shows that bank size has a positive impact on capital adequacy. This study results were also maintained by (Hyseni and Shiningjergji, 2015), which involved a positive correlation between bank size and capital adequacy ratio. The bigger the bank, the greater the capital adequacy obtained by the bank or the smaller the bank, the smaller the capital adequacy of a bank because the bank cannot increase the number of depositors in the bank so that the bank cannot generate more capital.

In addition, the results of bank size indicate a negative impression on capital adequacy ratios, as (Lestari et al., 2019), supported by the research institution (Bateni et al., 2014), among the banks, the larger banks have less risk, that is, the capital adequacy ratio Not as good as larger banks. Smaller large banks indicate that the bank has higher security. Banks have enough capital to take on risky assets, means that they have a lower level of risk and therefore their capital adequacy ratios are getting lower and lower. According to the research of (Margaretha and Setiyaningrum, 2011) faced out that there is no relationship between bank size and the capital adequacy ratio. 
Loan Loss Reserves. Concept of careful regulation and supervision of banks to make sure that banks set Loan Loss Provisions (LLP) at a level equal to the level of possibility in their loan portfolios (Mohd et al., 2015) Loan loss provisions are funds that come from part of the cash equivalents or bank's cash that is reserved to cover the estimated potential loss in the credit investment portfolio, because there is no need to save existing reserve funds. (Xuan and Ngoc, 2017) said that a measurement tool can be used to calculate the bank's loan loss reserve, that is, to calculate the loan loss provisions ratio to total loans.

Based on research conducted by (Ahmet, 2011) the Loan Loss Reserve (LLR) has a certain result on the capital adequacy ratio. The bank's loan loss reserve will be high, which means that the impairment loss reserve is also high, and the capital adequacy ratio is also high, because when calculating the capital adequacy ratio of component tier I (core capital), one of the components is the general reserve or so-called impairment loss reserve of asset write-off reserve, the higher the value of the bank's impairment loss reserve, the higher the capital adequacy ratio can be. From the results of previous research by (Lestari et al., 2019), it is obtained that LLR have a negative influence on capital adequacy ratio. Research that following these results is (Ngoc and Xuan, 2017), who establish that loan loss reserves have a negative impact on capital adequacy. This shows that a large amount of loss reserves indicates poor loan quality. Due to the existence of many bad credits, it will have a effect on the decreasing bank capital level.

Return on Equity. Return on Equity (ROE) measures bank profits and returns to equity shareholders. Commercial banks generally obtain funds from retained earnings or new stock issues. The higher rate of return enables banks to obtain funds from retained earnings. High returns also make banks more attractive in raising funds (Phuong and Duc, 2020). The return on equity can also be called the return to the owner. As the return of the owner's investment in the bank, this ratio is one of the greatest important ratios because the owner can decide to maintain empowering in the bank. Transfer investment to more activities that generate returns (Moh'ad Al-Tamimi and Fakhri Obeidat, 2013).

The research results conducted by (Kurniawan and Lestari, 2014) expose that profit on equity has a considerable negative impact on capital adequacy. These results are reliable with the study of (Ahmet, 2011), and the result is that the return on equity has a significant negative effect on the capital adequacy ratio. The greater the amount of capital owned, the lower the return on equity held by the bank. When a bank feels that the capital it owns needs to be strengthened, it will choose to use retained earnings to strengthen its capital with the consequence that the dividend given will decrease. If the bank management believes that there will be no losses due to financing problems, so there is no need to strengthen the risk bearing, then the bank will reduce the amount of capital to increase its equity mulplierwhich in turn will increase return on equity.

According to the research results tested by (Bateni et al., 2014), the results show that the return on equity has a positive effect on the capital adequacy ratio. ROE is a amount of profitability. It shows the realization level of the bank's own capital after tax net profit. The higher the return on equity obtained by the bank, the higher the net profit after tax, which means that the possibility of accumulating retained earnings will increase, so its own capital will increase, and it is estimated that the bank's capital adequacy ratio will 
increase. The research results of (Thoa et al., 2020) show that the ROE has no effect on the capital adequacy ratio.

Liquidity Ratio. Liquidity is an extraordinary aspect that determines the financial condition of a bank. Liquidity demonstrates the bank's capability to meet its obligations to depositors. The bank's image is strongly reflected in the liquidity risk. The liquidity is an important aspect that reflects a bank's ability to meet loan demand and cash flow needs. Banks can obtain sufficient liquidity if they have adequate liquidity (Aspal and Nazneen, 2014).

Increasing bank liquidity can have a positive effect on capital ratios. The high liquidity possessed by the bank will enable the bank to immediately meet the withdrawal and loan requirements of depositors. Conversely, when the liquidity of the bank is low, the bank is unable to fulfill the depositors' request for credit withdrawals and disbursements. (Phuong and Duc, 2020) pointed out that with the ratio of equity investments to cash, the bank's liquidity risk would lead to a decrease in the liquidity premium of the earn profit margin. Consequently, an encourage in the bank's liquidity may have a positive effect on the capital ratio.

A previous study conducted by (Aspal and Nazneen, 2014) showed that there is a significant and positive impact between the capital adequacy ratio and liquidity. These results are supported by the research of (Xuan Toha and Ngoc Anh, 2017), which shows that liquidity has a significant positive impact on capital adequacy ratio, since banks has adequate reserves to withdraw customers to the greatest extent and protect banks' capital affected by potential losses. The research results of (Thoa et al., 2020) are inversely proportional to previous research, that is, liquidity has a significant negative impact on capital adequacy ratios. The higher liquidity, the higher the level of bank liquidity. The risk of bank liquidity conditions. Lower liquidity indicates a lack of effectiveness. Banks guide credit. The higher the liquidity ratio, the lower the capital adequacy ratio, because a high liquidity ratio indicates that the higher the allocation of risky assets, the bank's liquidity situation is threatened. According to the research results of (Margaretha and Setiyaningrum, 2011), it shows that liquidity has a important negative impact on capital adequacy ratio. Therefore, the more funds deposited in current assets, the greater the capital cost to bear. If the bank's income is unbalanced with the income that caused the bank's losses and lack of capital, the bank will bear it.

Loan Ratio. The ratio used to measure the impact of loans on investment portfolios (Dreca, 2013). The risk accepted by the bank is also high, if the loan provided by the bank increases. Banks need to be aware of the bad credit risks. The upsurge in risk leashes to a high proportion of capital used to compensate depositors, since banks bear a high level of risk. The loan ratio determines the credit amount a bank has on the properties it owns. The higher ratio, the poorer the bank's liquidity, which means that the bank cannot repay shortterm debt because the bank's assets are insufficient to fund the bank's promised loan. (Bateni et al., 2014). (Xuan Toha and Ngoc Anh, 2017) stated that a formula can be used to calculate the ratio of bank loans to assets by dividing total loans by total assets.

Results of research lead by (Lestari et al., 2019) shows that the loan ratio has a significant negative impact on the capital adequacy ratio. The research is consistent with 
the research lead by (Xuan Toha and Ngoc Anh, 2017), which shows that loan ratios have a significant negative impact on capital adequacy ratios. The higher the credit risk rating of a bank, the lower its credit risk. Capital adequacy ratio. This shows that if the credit (loan) delivered by the bank increases, the risk that the bank will face is also high. The banks need to be aware of the bad credit risks. The higher the loan ratio, the worse the bank's liquidity, which indicates that the bank cannot meet its short-term debt because the bank has insufficient assets to fund the promised loan. According to the research results of (Bateni et al., 2014) and (Aspal and Nazneen, 2014), it is establish that the loan ratio has a positive impact on the capital adequacy ratio, indicates that as loans increase and down payment, profitability and interest income will increase. Which means that banks have a higher incentive to protect the owner's capital.

Conceptual Framework. The Capital Adequacy Ratio (CAR) is the using ratio by banking regulators to make certain that banks can establish the capital adequacy level and assess the health of the banking system from possible losses in bank managements (Nazneen and Aspal, 2014). A higher the capital adequacy ratio, as stronger the bank's strength and the higher the bank's ability to defend reserves from investors. The ratio make certain that the bank can assemble its requirements and other risks for example credit risk, operational risk and market risk. (Thoa et al., 2020) believe that the capital adequacy ratio presents the internal power of a bank that experiences sufferers through a crisis. In his research, he also studied factors that affect bank capital adequacy ratios, such as bank size, return on equity, loan loss reserves, liquidity ratio, and loan ratio.

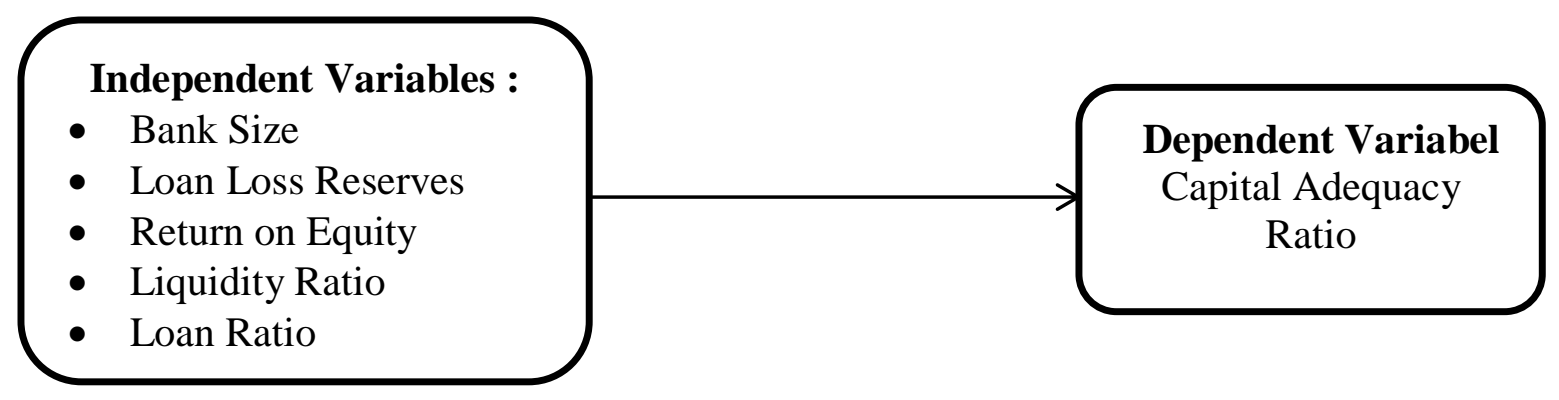

Figure 1. Conceptual Framework

\section{Hypothesis Development}

Bank size has an influence on the capital adequacy ratio. Basen on the results of (Ahmet, 2011), it shows that bank size has a positive impact on capital adequacy. This study results were also sustained by (Shiningjergji and Hyseni, 2015), which involved a positive relationship between bank size and the capital adequacy ratio. The larger the bank, the greater the capital adequacy that the bank obtains. Furthermore, the results of the test bank scale show a negative effect on the capital adequacy ratio, as (Lestari et al., 2019) was supported by research Bateni et al. (2014). Then, the first hypothesis can be stated as: 
$\mathbf{H}_{1}$ : Bank size has an influence on the capital adequacy ratio.

Loan loss reserve has an influence on the capital adequacy ratio. According to the research results of (Ahmet, 2011), it shows that the LLR has a positive impact on the CAR. A higher the bank's loan loss reserve level, the higher the credit loss reserve. The capital adequacy ratio is also needed to make up for the bank's losses due to each risky credit. The results of a previous study conducted by (Lestari et al., 2019) recovered that loan loss reserves have a negative impact on capital adequacy. The research following these results is (Xuan Toha and Ngoc Anh, 2017), who realized that loan loss reserves have a negative impact on capital adequacy. Then, the second hypothesis can be expressed as:

$\mathbf{H}_{2}$ : Loan loss reserves have an effect on the capital adequacy ratio.

Return on equity has an influence on the capital adequacy ratio. The results of research lead by (Kurniawan and Lestari, 2014) present that return on equity has a significant negative result on capital adequacy. This results are reliable with the study of (Ahmet, 2011), and the result is that the return on equity has a significant negative effect on the capital adequacy ratio. According to the research results tested by Bateni et al. (2014), the results show that the return on equity has a positive result on the capital adequacy ratio. A higher the bank return on equity, the higher the bank's capital adequacy ratio. Then, the third hypothesis can be stated as:

$\mathbf{H}_{3}$ : Return on equity has an influence on the capital adequacy ratio.

The liquidity ratio has an influence on the capital adequacy ratio. A previous study conducted by (Aspal and Nazneen, 2014) showed that there is a significant and positive impact between the capital adequacy ratio and liquidity. These findings are supported by the research of (Xuan Toha and Ngoc Anh, 2017), which shows that liquidity has a significant positive impact on capital adequacy ratio, since banks have adequate assets to withdraw customers to the greatest extent and protect banks' capital Affected by potential losses. The research results conducted by (Thoa et al., 2020) are inversely proportional to previous research, that is, liquidity has a important negative impact on capital adequacy. Then, the fourth hypothesis can be stated as:

$\mathbf{H}_{4}$ : Liquidity ratio has an influence on the capital adequacy ratio.

The loan ratio has an influence on the capital adequacy ratio. The research results conducted by (Lestari et al., 2019) show that the loan ratio has a significant negative impact on the capital adequacy ratio. The research is consistent with the research showed by (Xuan Toha and Ngoc Anh, 2017), which shows that loan ratios have a significant negative impact on capital adequacy ratios. According to the research results of (Bateni et al., 2014) and (Aspal and Nazneen, 2014), it is establish that the loan ratio has a positive influence on the capital adequacy ratio. Then, the fifth hypothesis can be expressed as: 
H5 : Loan ratio has an influence on the capital adequacy ratio.

\section{METHODOLOGY}

Research Design. The research design that used is a hypothesis test to test the independent variables influence (ie, bank size, loan loss reserves, return on equity, liquidity ratio, and loan ratio) on the dependent variable namely the capital adequacy ratio. This research also analyzes banks registered on the Indonesian Stock Exchange from 2015 to 2019. The analytical method used for data processing is Eviews 10.0 to regress the panel data.

Variables and Measurement. The variables and measurements used in this study are to decide the correlation between the dependent variable and independent variable, each of which measures are as follows:

Table 2. Variable Measurement

\begin{tabular}{|c|c|c|c|c|}
\hline $\begin{array}{c}\text { Variables } \\
\text { Type }\end{array}$ & Variables Name & Proxy & Variables Measurement & Source \\
\hline $\begin{array}{l}\text { Dependent } \\
\text { Variable }\end{array}$ & $\begin{array}{c}\text { Capital Adequacy } \\
\text { Ratio }\end{array}$ & CAR & $\frac{\text { tier } 1+\text { tier } 2}{\text { risk weighted asset }}$ & (Hunjra et al., 2020) \\
\hline \multirow{5}{*}{$\begin{array}{l}\text { Independent } \\
\text { Variables }\end{array}$} & Bank Size & SIZE & Logarithma Natural of Total Asset & \multirow{5}{*}{ (Thoa et al., 2020) } \\
\hline & Loan Loss Reserves & LLR & $\frac{\text { Loan Loss Provision }}{\text { Total Loans }}$ & \\
\hline & Return on Equity & ROE & $\frac{\text { Net Income }}{\text { Total Equity }}$ & \\
\hline & Liquidity Ratio & LIQ & $\frac{\text { Liquid Asset }}{\text { Total Asset }}$ & \\
\hline & Loan Ratio & LOA & $\frac{\text { Total Loans }}{\text { Total Asset }}$ & \\
\hline
\end{tabular}

Data Collection Methods. The data collection method used is secondary data collection, where data is obtained indirectly from available sources. The data source for this study can be obtained from the website of the Indonesian Stock Exchange (https://www.idx.co.id). Research data includes banking companies from 2015 to 2019.

Sampling Method. The sampling method used in this study is purposeful sampling, in which the population used as the research sample is a company that meets certain conditions. The data standards that will be selected as the research sample are following conditions: (1) Banking companies registered on the Indonesian Stock Exchange from 2015 to 2019. (2) The company has complete financial reports in accordance with the variables required in the study. 
Table 3. Sampling Method

\begin{tabular}{c|c}
\hline \multicolumn{1}{c|}{ Explanation } & Total \\
\hline Banking companies registered on the Indonesian Stock Exchange from 2015 to 2019 & 43 \\
\hline Banking companies with incomplete financial reports & $(1)$ \\
\hline Total Sample & $\mathbf{4 2}$ \\
\hline Total Observations (5 years x 42 banks) & $\mathbf{2 1 0}$ \\
\hline
\end{tabular}

\section{RESULTS}

Data Testing Methods. In testing the regression analysis, there are three models, namely The and random effect, common effect model and fixed effect. In determining the suitable capital for interpretation, two test phases were performed, namely the Hausman test and the Chow test.

Chow Test. The Chow test is a test used to select a model that is suitable for research, that is, a fixed and common effect model. The Chow test is based on the null hypothesis and does not have individual heterogeneity. An alternative hypothesis is cross-section heterogeneity.

Hausman Test. The Hausman test is a test used to prefer the greatest model between a random and fixed effect model. The hausman test can also be used to see which of the characteristics of each model to be used between fixed effects and random effects are heterogeneous.

Several stages in panel data testing are as follows:

Table 4. Result of Model Test

\begin{tabular}{c|c|c|c}
\hline Methods & Prob. & Decision & Explanation \\
\hline Chow Test & 0.0000 & $\mathrm{H}_{0}$ rejected & Fixed Effect \\
\hline Hausman Test & 0.0001 & $\mathrm{H}_{0}$ rejected & Fixed Effect \\
\hline
\end{tabular}

Sourcer : Data Ouput E-Views 10.0

From the above calculation results, it is shown that the cross sectional probability value of the chi-square is $0.0000<0.05$, and the decision to reject is $\mathrm{H} 0$, so the model used is a fixed effect. If the chosen model is a fixed effects model, need to use Hausman's test for further testing to test whether to use a random or a fixed effects model.

By using the Hausman test to test, the result presents that the statistical cross-sectional probability value is $0.0001<0.05$, so the decision that can be drawn is to reject $\mathrm{H} 0$, so the model used is a fixed-effects model. Therefore, it can be concluded that among the three models (Random Effects, Fixed Effects, and Common Effects), the Fixed Effects model is better at explaining panel data regression to meet the research goals.

F Test. Perform an F test to test the independent variables, namely loan loss reserve, bank size, return on equity, liquidity ratio, and loan ratio, and test them together to see if the 
independent variables jointly pretend the dependent variable, namely the capital adequacy ratio.

According to the test results, the $\mathrm{F}$ statistical probability value is $0.000000<0.05$. Therefore, the analysis this study results show that independent variables such as bank size, loan loss reserves, return on equity, liquidity ratio, and loan ratio have an impact on capital adequacy ratio, so the regression model is suitable for use in this study.

Goodness Test of Fit (Adjusted $\mathbf{R}^{\mathbf{2}}$ ). At this testing stage, all independent variables are tested to see whether the independent variables, namely bank size, loan loss reserves, return on equity, liquidity ratio and loan ratio in this model are capable for explain variations of the dependent variable, namely the capital adequacy ratio.

According to the goodness results of fit, the adjusted $r$-squared value is 0.718330 . This earnings that the independent variables of bank size, loan loss reserves, return on equity, liquidity ratio, and loan ratio can explain the change in capital adequacy ratio of $71.3029 \%$, thus making the bank size and loans have a strong relationship. Loss reserves, liquidity, return on net assets. The ratio of the loan to asset ratio to the capital adequacy ratio, the remaining $28.6971 \%$ explained that the capital adequacy ratio may be pretended by other influences not included in this model.

Data Analysis Method. This regression analysis purposes to examine the effect of loan loss reserves, bank size, return on equity, liquidity ratio and loan ratio as independent variables on the dependent variable, namely the capital adequacy ratio. The regression equation is as follows:

$\mathrm{CAR}_{i t}=\alpha_{0}+\beta_{1} \mathrm{SIZE}_{i t}+\beta_{2} \mathrm{LLR}_{i t}+\beta_{3} \mathrm{ROE}_{i t}+\beta_{4} \mathrm{LIQ}_{i t}+\beta_{5} \mathrm{LOA}_{i t}+\mathrm{e}_{i t} \ldots \ldots \ldots \ldots$

Information:

$\begin{array}{ll}\operatorname{CAR}_{i t}\left(\mathrm{Y}_{1}\right) & =\text { Capital Adequacy Ratio } \\ \operatorname{SIZE}_{i t}\left(\mathrm{X}_{1}\right) & =\text { Bank Size } \\ \operatorname{LLR}_{i t}\left(\mathrm{X}_{2}\right) & =\text { Loan Loss Reserves } \\ \operatorname{ROE}_{i t}\left(\mathrm{X}_{3}\right) & =\text { Return on Equity } \\ \operatorname{LIQ}_{i t}\left(\mathrm{X}_{4}\right) & =\text { Liquidity Ratio } \\ \operatorname{LOA}_{i t}\left(\mathrm{X}_{5}\right) & =\text { Loan Ratio } \\ \mathrm{e}_{i t} & =\text { error team }\end{array}$




\section{DISCUSSION}

Statistics Descriptive Results. Descriptive statistical results of the research variables used are presented below:

Table 5. Descriptive Statistics

\begin{tabular}{l|c|c|c|c|c}
\hline \multicolumn{1}{c|}{ Variabel } & N & Mean & Min. & Max. & Std. Dev \\
\hline Capital Adequacy Ratio & 210 & 0.200411 & 0.080200 & 0.664300 & 0.079851 \\
\hline Bank Size & 210 & 13.57346 & 12.29540 & 15.15130 & 0.771290 \\
\hline Loan Loss Reserve & 210 & 0.029754 & 0.000600 & 0.310300 & 0.032858 \\
\hline Return on Equity & 210 & 0.049700 & -1.066000 & 0.677300 & 0.146633 \\
\hline Liquidity Ratio & 210 & 0.212116 & 0.040600 & 0.536100 & 0.097804 \\
\hline Loan Ratio & 210 & 0.615592 & 0.009430 & 0.891600 & 0.153835 \\
\hline
\end{tabular}

Source : Output regresi data panel E-Views 10.0

\section{Data Analysis}

Panel Data Regression Analysis. An analysis of panel data regression method was carried out to examine the influence of independent variables such as loan loss reserves, bank size, return on equity, liquidity ratio and loan ratio on the dependent variable, namely the capital adequacy ratio. The following are the results of the regression equation in the research:

$$
\begin{aligned}
& \mathrm{CAR}_{i t}=-0.714914+0.075104 \text { SIZE }_{i t}-0.076570 \text { LLR }_{i t}+0.034260 \text { ROE }_{i t}+ \\
& 0.090044 \text { LIQ }_{i t}-0.199192 \text { LOA }_{i t}
\end{aligned}
$$

Hypothesis (T) Test. The $T$ test is designed to test the regression coefficient of each independent variable on the dependent variable. Discovery how independent variables namely loan loss reserve, bank size, liquidity ratio, return on equity and loan ratio affect the dependent variable namely the bank's capital adequacy ratio.

Decision making criteria:

- $\quad$ If sig. probability $\mathrm{t}>0.05$ then $\mathrm{H}_{0}$ is accepted

- If sig. probability $\mathrm{t}<0.05$ then $\mathrm{H}_{0}$ is rejected.

The following table 6 presents the results of the $t$ test for each of the variables used in the study: 
Table 6. T-Test Results

\begin{tabular}{c|c|c|c}
\hline \multirow{2}{*}{ Independent Variables } & \multicolumn{3}{|c}{ Dependent Variable } \\
\cline { 2 - 4 } & \multicolumn{3}{|c}{ CAR } \\
\cline { 2 - 4 } & Coefficient & Probability & Conclusion \\
\hline Constanta & -0.714914 & - & - \\
\hline SIZE & 0.075104 & 0.0000 & Signficant \\
\hline LLR & -0.076570 & 0.2697 & Not Significant \\
\hline ROE & 0.034260 & 0.0264 & Significant \\
\hline LIQ & 0.090044 & 0.3485 & Significant \\
\hline LOA & -0.199192 & 0.0000 & Significant
\end{tabular}

Source : Output regresi data panel E-Views 10.0

According to the results in Table 6, the influence of each independent variable on the dependent variable give details as follows:

Bank Size has a probability value of $0.0000<0.05$. The amount of the coefficient is 0.075104 . The results of this study concluded that bank size has a significant and positive effect on capital adequacy. This is constant with (Ahmet, 2011) and (Shiningjergji and Hyseni, 2015), namely bank size has a positive significant effect on capital adequacy. A large scale of the bank earnings that the total assets owned by the bank are also increasing. Therefore, banks with sufficient surplus assets will be able to obtain capital requirements from the operating profits of the relevant banks, and the operating profits will continue to develop. As well as being able to encourage the management to make a bigger investment expansion, the greater the operational investment made will increase the profits. By increasing the profits obtained will result in an increase in CAR.

Loan Loss Reserves have a probability value of $0.2697>0.05$. The research results show that the loan loss reserve has no impact on the capital adequacy ratio. The amount of impairment loss reserves owned by banks will not affect the amount of capital adequacy ratios. This shows that the banks in the research sample have good credit quality, because from the descriptive statistics of variable loan loss reserves, almost all percentages are below 5\%. This means that the bank has a good credit quality, so the provision for impairment losses is also small, and will not affect the bank's capital adequacy ratio.

Return on Equity has a probability value of $0.0264<0.05$. The amount of the coefficient is 0.034260 . This study results concluded that return on equity has a significant and positive impact on capital adequacy. This is consistent with the discoveries of (Bateni et al., 2014), which show that return on equity has a positive effect on capital adequacy. Return on equity is a measure of profitability. It shows the realization level of after-tax net profit on the bank's own capital. The higher the return on equity achieved by the bank indicates that the net profit after tax is also higher, which means that the possibility of accumulated retained earnings increases, so that its own capital will increase and it is estimated that a bank's capital adequacy ratio will increase. 
Liquidity Ratio has a probability value of $0.3485>0.05$. The research results show that there is no impact between the liquidity ratio and the capital adequacy ratio. The size of the bank's liquidity ratio does not affect the capital adequacy ratio owned by the bank. This refers to the results of the descriptive statistics in this study. The average liquidity ratio is $21.21 \%$ and the maximum is $53.61 \%$. This shows that banks with high liquidity value can also be said to be bad for banks, because liquid assets such as cash and securities in banks will not get a high rate of return. In this way, shareholders will not want the company to invest too much in liquid assets. Companies also need to strike a balance between the security requirements provided by liquidity and the low returns that liquid assets bring to investors.

Loan Ratio has a probability value of $0.0000<0.05$. The amount of the coefficient is 0.199192 . This study results concluded that loan ratios have a significant and negative impact on capital adequacy ratios. These results are reliable with the research conducted by (Lestari et al., 2019) and (Xuan Toha and Ngoc Anh, 2017), which showed that loan ratios have a negative impact on capital adequacy ratios. The higher the bank's credit risk level, the lower the capital adequacy ratio. This shows that if the credit (loan) provided by the bank increases, the risk that the bank will face is also high. The banks need to be aware of the risks of bad credit. The higher the loan ratio, the worse the bank's liquidity, which indicates that the bank cannot meet its short-term debt because the bank has insufficient assets to fund the promised loan. So that the bank's capital will also be eroded to compensate for these funds because the bank has dared to take high risks.

\section{CONCLUSION}

Managerial Implications. According to the completed research results, it is obtained that return on equity and bank size have a positive impact on capital adequacy ratio, capital adequacy ratio and loan loss reserve have a negative effect on capital adequacy ratio and loan ratio has a negative effect on liquidity ratio. It has no effect on the capital adequacy ratio of banking companies listed in Indonesia. Therefore, the management meanings that can be used are as follows:

Companies. Capital adequacy ratio has a very important role in bank capital. A high capital adequacy ratio proves the bank's sound condition and is the strength of its internal funds to bear the risk. For this reason, bank managers must pay attention to what factors will influence the decision to decrease or increase the bank's capital adequacy. The variables in this study that have a significant impact on changes in the capital adequacy ratio are the size of the bank, the rate of return on capital and the loan ratio. Bank managers must increase and optimize the use of their total assets. This is do by the bank to preventuse of total assets excessive for unproductive bank activities which causes the capital ratio to decrease and causes the impact of losses received by the bank. Bank managers must also increase return on equity so that the bank's capital ratio remains safe and does not experience a decline and remains above the minimum capital requirement. Banks should lower their loan ratio to keep it stable. If their loan ratio increases, it will have an impact on the possible risk of loss due to a decrease in the capital ratio. 
Investor. For investors, before deciding to invest, they must pay attention to the assets amount owned by the bank, have an annual return on equity, and pay consideration to loan requirements to prevent bad credit risks. This is important for consideration and readiness of investors, whether the bank to be invested can save investor funds if the bank goes bankrupt.

Conclusion. This research purposes to analyze the impact of return on equity, loan loss reserves, bank size, liquidity ratio and loan ratio on capital adequacy ratios of banking companies registered on the Indonesian Stock Exchange (IDX). A total of 42 companies were sampled 2015-2019. From all the research variables, bank size and return on equity have a significant positive impact on capital adequacy. The loan ratio has a significant negative impact on the capital adequacy ratio. All at once, the variable liquidity ratio and loan loss reserve have no effect on the capital adequacy ratio.

Limitation and Recommendation. According to the results of the study, the study still has limitations, that is, the variables used in the study are limited, that is, the use of variables bank size, loan loss reserve, return on equity, liquidity ratio and loan ratio to determine the effect. Capital adequacy ratio. Suggestions can be given to further researchers by adding other independent variables to measure the capital adequacy ratio, such as: leverage, net interest margin (Lestari et al., 2019). interest margin on loans, quick ratio (Caroline, 2011).

\section{REFERENCES}

Afzal, A. (2015). The Impact of Market Discipline on Banks' Capital Adequacy : Evidence From an Emerging Economy. 1(Autumn), 61-73. https://doi.org/10.35536/ljb.2015.v4.i1.a4

Ahmet Büyükşalvarci. (2011). Determinants of capital adequacy ratio in Turkish Banks: A panel data analysis. African Journal of Business Management, 5(27), 11199-11209. https://doi.org/10.5897/ajbm11.1957.

Ashraf, B., Arshad, S., and Hu, Y. (2016). Capital Regulation and Bank Risk-Taking Behavior: Evidence from Pakistan. International Journal of Financial Studies, 4(3), 16. https://doi.org/10.3390/ijfs4030016.

Aspal, P. K., and Nazneen, A. (2014). An Empirical Analysis of Capital Adequacy in the Indian Private Sector Banks. American Journal of Research Communication, 2(11), 28-42. http://www.usa-journals.com/wpcontent/uploads/2014/10/Aspal_Vol211.pdf.

Bateni, L., Vakilifard, H., and Asghari, F. (2014). The Influential Factors on Capital Adequacy Ratio in Iranian Banks. International Journal of Economics and Finance, 6(11), 108-116. https://doi.org/10.5539/ijef.v6n11p108.

Berger, A. N., and Turk-Ariss, R. (2015). Do Depositors Discipline Banks and Did Government Actions During the Recent Crisis Reduce this Discipline? An International Perspective. Journal of Financial Services Research, 48(2), 103-126. https://doi.org/10.1007/s10693-014-0205-7.

Caroline barus, A. (2011). Analisis Profitabilitas dan Likuiditas terhadap Capital Adequacy Ratio (CAR) pada Institusi Perbankan Terbuka di Bursa Efek Indonesia. 
Jurnal Wira Ekonomi Mikroskil, 1(April), 1-12. https://www.mikroskil.ac.id/ejurnal/index.php/jwem/article/view/51/40.

Dreca, N. (2013). Determinants of Capital Adequacy Ratio in Selected Bosnian. Journal of Social Sciences, 12(1), 149-162. https://silo.tips/download/determinants-ofcapital-adequacy-ratio-in-selected-bosnian-banks.

Fullenkamp, C., and Rochon, C. (2017). Reconsidering bank capital regulation: a new combination of rules, regulators, and market discipline. Journal of Economic Policy Reform, 20(4), 343-359. https://doi.org/10.1080/17487870.2016.1181550.

Gabriel Ogere, A., Peter, Z., and Inyang, E. (2013). Capital Adequacy Ratio and Banking Risks in the Nigeria Money Deposit Banks. Research Journal of Finance and Accounting, 4(17), 2222-2847. https://iiste.org/Journals/index.php/RJFA/article/view/8972/9205.

Hunjra, A. I., Zureigat, Q., and Mehmood, R. (2020). Impact of capital regulation and market discipline on capital ratio selection: A cross country study. International Journal of Financial Studies, 8(2), 1-13. https://doi.org/10.3390/ijfs8020021.

Isa, M., Yaziz, M., Choong, Y. V., Gun Fie, D. Y., and Abdul Rashid, M. Z. (2015). Loan Loss Reserves (LLR), Expected Loss (EL), and Value at Risks (VaR). Journal of Modern Accounting and Auditing, 11(4), 218-222. https://doi.org/10.17265/15486583/2015.04.004.

Jumreornvong, S., Chakreyavanich, C., Treepongkaruna, S., and Jiraporn, P. (2018). Capital Adequacy, Deposit Insurance, and the Effect of Their Interaction on Bank Risk. Journal of Risk and Financial Management, 11(4), 79. https://doi.org/10.3390/jrfm11040079.

Kurniawan, A. T., dan Lestari, S. (2014). Analisis Faktor-Faktor Yang Mempengaruhi Capital Adequacy Ratio (Car). Jp Journal \& Proceeding, 4(1), 908-918. http://jp.feb.unsoed.ac.id/index.php/sca-1/article/view/727.

Lestari, H. S., Usman, B., and Puspa, T. (2019). Determinants of capital adequacy ratio on banking industry: Evidence in Indonesia Stock Exchange. Jurnal Keuangan Dan Perbankan, 23(3), 443-453. https://doi.org/10.26905/jkdp.v23i3.2981.

Margaretha, F., dan Setiyaningrum, D. (2011). Pengaruh Resiko, Kualitas Manajemen, Ukuran dan Likuiditas Bank terhadap Capital Adequacy Ratio Bank-Bank yang Terdaftar di Bursa Efek Indonesia. Jurnal Akuntansi Dan Keuangan, 13(1), 47-55. https://doi.org/10.9744/jak.13.1.47-56.

Masood, Usman. Ansari, S. (2016). Determinants of Capital Adequacy Ratio. Pakistani Banking Sector. International Journal of Economics, Commerce, and Management, IV(7), 149-162. http://ijecm.co.uk/wp-content/uploads/2016/07/4716.pdf.

Moh'ad Al-Tamimi, K. A., and Fakhri Obeidat, S. (2013). Determinants of Capital Adequacy in Commercial Banks of Jordan an Empirical Study. International Journal of Academic Research in Economics and Management Sciences, 2(4), 267280. https://doi.org/10.6007/ijarems/v2-i4/53.

Phuong, H., and Duc, N. (2020). Determinants influencing capital adequacy ratio of Vietnamese commercial banks. 6, 871-878. https://doi.org/10.5267/j.ac.2020.5.007.

Shingjergji, A., and Hyseni, M. (2015). The Determinants of the Capital Adequacy Ratio in the Albanian Banking System During 2007 - 2014. International Journal of Economics, Commerce and Management, 3(1), 1-10. https://doi.org/2348-0386. 
Stolz, S., and Wedow, M. (2011). Banks' regulatory capital buffer and the business cycle: Evidence for Germany. Journal of Financial Stability, 7(2), 98-110. https://doi.org/10.1016/j.jfs.2009.09.001.

Thoa, P. T. X., Anh, N. N., and Minh, N. K. (2020). The determinant of capital adequacy ratio: Empirical evidence from Vietnamese banks (a panel data analysis). Afro-Asian Journal of Finance and Accounting, 10(1), 60-70. https://doi.org/10.1504/AAJFA.2020.104406.

Xuan Toha, P. T., and Ngoc Anh, N. (2017). The Determinants of Capital Adequacy Ratio: The Case of the Vietnamese Banking System in the Period 2011-2015. VNU Journal of Science: Economics and Business, 33(2), 49-58. https://doi.org/10.25073/2588-1108/vnueab.4070. 